\title{
STRATEGI PEMBINAAN AKHLAKUL KARIMAH MELALUI KEGIATAN EKSTRAKURIKULER PADA SISWA KELAS IV B MIN TOLOBALI KOTA BIMA
}

\author{
Aryulianti, Sukrin, Abdussahid, Nurdiniawati \\ Institut Agama Islam (IAI) Muhammadiyah Bima \\ Emai: aryulianti@gmail.com, sukriniaim@gmail.com, \\ abdussahid@gmail.com
}

\begin{abstract}
Abstrak:
Penelitian ini bertujuan untuk mendeskripsikan gambaran tentang strategi pembinaan akhlakul karimah melalui kegiatan ekstrakurikuler pada siswa kelas IV B MIN Tolobali Kota Bima. Penelitian yang dipergunakan dalam penelitian ini adalah penelitian kualitatif. Sumber data dalam penelitian ini terdiri dari kepala sekolah, wakasek kurikulum, guru bahasa indonesia dan matematika, serta siswa kelas IV B sebanyak 5 orang siswa MIN Tolobali Kota Bima. Teknik pengambilan sampel dilakukan melalui observasi, wawancara, dan dokumentasi. Masalah dalam penelitian yang akan dicapai; pertama, bagimana bentuk pembinaan akhlakul karimah melalui kegiatan ekstrakurikuler sehingga mampu memanimalisir permasalahan yang terjadi pada siswa. Kedua, apa faktor penghambat yang mempengaruhi pembinaan akhlakul karimah dalam diri siswa melalui kegiatan ekstrakurikuler yang telah dikembangkan oleh sekolah pada Siswa Kelas IV B MIN Tolobali Kota Bima, Hasil penelitian menunjukan bahwa bentuk pembinaan akhlakul karimah di MIN Tolobali Kota Bima melalui kegiatan ekstrakurikuler meliputi kegiatan a) kegiatan english club, b) kegiatan arabian club, c) kegiatan pembinaan olimpiade matematika dan sains, d) kegiatan pramuka, e) kegiatan pembinaan drumband, f) kegiatan pembinaan tahfiz, dan g) kegiatan olahraga. Adapun faktor penghambat dalam pembinaan akhlakul karimah melalui kegiatan ekstrakurikuler pada siswa kelas IV B MIN Tolobali Kota Bima ini ada beberapa khususnya setelah pandemi dapat diuraikan sebagagai berikut: a) jarak atau kegiatan belajar mengajar yang dilakukan secara daring, b) bullying, karena menghambat proses pembinaan akhlakul karimah siswa, c) kondisi lingkungan keluarga, dan d) kecenderungan siswa dalam bermain game.
\end{abstract}

Kata Kunci: Pembinaan, Akhlakul Karimah, Kegiatan Ekstrakurikuler.

\section{PENDAHULUAN}

$\mathrm{K}$

unci utama pembangunan bangsa di masa mendatang adalah pendidikan. Sebab dengan pendidikan diharapkan setiap individu dapat meningkatkan kualitas keberadaannya dan mampu berpartisipasi dalam gerak pembangunan. Dengan pesatnya perkembangan dunia di era globalisasi ini, terutama di bidang teknologi dan ilmu pengetahuan, maka pendidikan nasional juga harus terus-menerus dikembangkan seirama dengan zaman. Pada umumnya sebuah sekolah dan pendidikan bertujuan pada bagaimana kehidupan manusia itu 


\section{eL-Muhbib}

Jurnal Pemikiran dan Penelitian Pendidikan Dasar

ISSN 2614-1051 Volume 5 Nomor 2 Desember 2021

harus ditata, sesuai dengan nilai-nilai kewajaran dan keadaban. Semua orang pasti mempunyai harapan dan cita-cita bagaimana sebuah kehidupan yang baik. Karena itu pendidikan pada gilirannya berperan mempersiapkan setiap orang untuk berperilaku penuh keadaban. Keadaan inilah yang secara praktis sangat dibutuhkan dalam setiap gerak dan perilaku (Wahab, 2016). Pendidikan pada dasarnya merupakan bagian yang tidak terpisahkan dari kehidupan manusia. Dari mulai lahirnya manusia senantiasa belajar hal-hal terjadi di sekitarnya, hingga manusia lanjut usia bahkan meninggal dunia, ia tetap melakukan prakondisiprakondisi dalam melihat persoalan yang dihadapi, dan inilah proses pembelajaran (Syukurman, 2016). Melalui pendidikanlah manusia dapat di bentuk karakternya kearah yang lebih baik. Dengan peran serta pendidikan maka manusia dapat dimanusiakan. Orang yang berpendidikan dengan orang yang tidak berpendidikan dapat di nilai dari beberapa aspek seperti tingkah laku yang ditimbulkan, tutur kata yang di sampaikan, pengendalian emosi dalam menangani permasalahan yang di alaminya.

Adapun rentetan kegiatan yang tertuang dalam pendidikan salah satunya adalah kegiatan belajar mengajar. Belajar bisa dikatakan sesuatu yang dilakukan secara berulang dan bernilai ilmu pengetahuan, baik itu melalui pendidikan (formal, informal, dan non formal), maupun melalui pengalaman yang dialami oleh individu yang bersangkutan. Melalui belajarlah manusia dapat membentuk pola pikir dan pengetahuan yang ia inginkan. Dalam perspektif pendidikan terdapat tiga lembaga utama yang sangat berpengaruh dalam perkembangan kepribadian anak, yaitu lingkungan keluarga, lingkungan sekolah, dan lingkungan masyarakat. Kerjasama antara ketiga pihak tersebut merupakan faktor yang sangat menentukan dalam pencapaian tujuan pendidikan. Dalam era global dewasa ini, permasalahan kehidupan manusia mengalami perubahan yang sangat cepat. Hal ini menunjukkan bahwa kehidupan sehari-hari semakin tidak karuan dengan mengedepankan kekuatan dan uang bukan akhlak. Penindasan terhadap kaum lemah dan miskin menjadi pandangan yang biasa dalam lingkup masyarakat. Uang dan kekuasaan telah menguasai segalanya.

Pembinaan akhlak saat ini semakin diperlukan karena persoalan moral dan akhlak yang cukup serius. Melihat dari realita sekarang ini, hampir semua guru mengeluh bahwa generasi muda berani kepada guru, orang tua, berakhlak buruk, dan tidak memiliki sopan santun. Persoalan semacam ini kerap kali disiarkan dalam media massa. Misalnya praktek hidup yang menyimpang dan penyalahgunaan kesempatan dengan mengambil bentuk perbuatan yang sadis seperti perampokan, pemerkosaan, penyalahgunaan kekuasaan, perampasan hakhak asasi manusia, menyalahgunakan pengetahuan dan teknologi serta masalahmasalah umum lainnya. Akhlak yang sesuai ajaran Islam disebut akhlakul 


\section{eL-Muhbib}

Jurnal Pemikiran dan Penelitian Pendidikan Dasar

ISSN 2614-1051 Volume 5 Nomor 2 Desember 2021

karimah atau akhlak yang mulia yang dapat diperoleh dengan dua cara. Pertama, bawaan lahir, sebagai karunia dari Allah. Kedua, hasil usaha melalui pendidikan dan pengembangan jiwa.

Berangkat dari persoalan inilah, di beberapa sekolah menerapkan sistem yang harapannya akan mampu memanimalisir persoalan-persoalan tersebut melalui pengembangan kegiatan ektrakurikuler dengan metode pembiasaan untuk membentuk akhlakul karimah sebagai akhlak yang diharapkan terwujud dalam diri siswa. Dari hasil observasi awal peneliti bahwa, di MIN Tolobali termasuk sekolah yang unggul dan berprestasi. Berdasarkan persoalan dari gambaran di atas, maka peneliti ingin melakukan satu penelitian akademik yang berkaita dengan dengan judul "Strategi Pembinaan Akhlakul Karimah Melalui kegiatan Ekstrakurikuler Pada Siswa Kelas IV B MIN Tolobali Kota Bima".

\section{TINJAUAN TEORITIS}

\section{Pembinaan Akhlak dalam Islam}

Pembinaan berasal dari kata bahasa Arab "bana" yang berarti membina, membangun, mendirikan. Menurut kamus besar bahasa Indonesia, pembinaan adalah suatu usaha tindakan dan kegiatan yang dilakukan secara berdaya guna dan berhasil guna untuk memperoleh hasil yang baik. Pembinaan adalah suatu usaha yang dilakukan dengan sadar, sungguh-sungguh, terencana dan konsisten dengan cara membimbing, mengarahkan dan mengembangkan pengetahuan, kecakapan, dan pengamalan ajaran Islam sehingga mereka mengerti, memahami dan menerapkannya dalam dalam kehidupan sehari-hari (KBBI, 2008)..

Secara etimologi, akhlak berasal dari bahasa Arab khalaqu, khuluqun yang berarti tabiat atau perangai. Dalam pengertian ini, maka akhlak dapat bersifat positif, maupun negatif tergantung pada tatanan nilai yang menjadi landasannya. Istilah akhlak seringkali dipahami sebagai gambaran batin manusia dan perangai luar manusia. Selain itu akhlak juga diartikan sebagai budi pekerti, watak dan kesusilaan yang berdasarkan nilai atau moral kelompok masyarakat. Dalam pengertian ini, maka akhlak diartikan sebagai kelakuan baik yang merupakan akibat dari sikap jiwa yang benar terhadap khaliknya dan sesama. Akhlak juga diartikan sebagai suatu sikap dan perilaku yang tertanam dalam batin yang dari padanya timbul perilaku. Karena akhlak merupakan salah satu gambaran batiniah yang digambarkan dalam watak, sikap, dan perilaku, maka gambaran ini sangatlah abstrak dan bersifat pribadi.

Pada garis besarnya akhlak dibagi menjadi dua yaitu akhlak kepada Allah dan makhluk ciptaan Allah SWT. Dapat disimpulkan bahwa akhlak merupakan sistem perilaku yang dibuat oleh manusia sebagai akibat dari kebiasaan hidup yang sesuai dengan kaidah dan ketentuan normatif agama. Pendekatan yang 


\section{eL-Muhbib}

Jurnal Pemikiran dan Penelitian Pendidikan Dasar

ISSN 2614-1051 Volume 5 Nomor 2 Desember 2021

digunakan dalam memahami dan menilai akhlak ada dua yakni 1) Stimulus respon (rangsangan-jawaban) melalui latihan, tanya jawab proses meniru. 2) Kognitif yaitu penyampaian secara teoritis dalam memengaruhi perilaku orang lain (Hasanah, 2016).

Dalam pengertian yang lebih luas akhlak yang dituntunkan ajaran Islam adalah Akhlakul Karimah yaitu akhlak sebagai wujud perilaku yang timbul dari pranata nilai sebagai atribut kualitatif pribadi, sedangkan orang yang berakhlak karimah disebut dengan muhsin. Adapun tujuan penanaman nilai-nilai akhlakul karimah diantaranya:

a. Menumbuhkan pembentukan kebiasaan berakhlak mulia dan beradat kebiasaan yang baik.

b. Memantapkan rasa keagamaan pada siswa, membiasakan diri berpegang pada akhlak mulia dan membenci akhlak yang rendah.

c. Membiasakan siswa bersikap rela, optimis, percaya diri, menguasai emosi, tahan menderita dan sabar.

d. Membimbing siswa kearah sikap yang sehat yang dapat membantu mereka berinteraksi sosial yang baik, mencintai kebaikan untuk orang lain, suka menolong, sayang kepada yang lemah dan menghargai orang lain.

e. Membiasakan siswa bersopan santun dalam berbicara dan bergaul baik di sekolah maupun di luar sekolah.

f. Selalu tekun beribadah dan mendekatkan diri kepada Allah dan bermuamalah yang baik (Hasanah, 2016).

\section{Macam-Macam Akhlak dalam Islam}

Akhlak Islami ialah akhlak yang berdasarkan ajaran Islam atau akhlak yang bersifat Islami. Kedudukan akhlak dalam kehidupan manusia mempunyai tempat yang penting secara individu maupun anggota masyarakat. Adapun pembagian akhlak tersebut sebagai berikut:

a. Akhlak manusia sebagai hamba Allah (Akhlak kepada Allah). Akhlak kepada Allah SWT dapat diartikan sebagai sikap atau perbuatan yang sehsrusnya dilakukan oleh manusia sebagai makhluk Allah SWT, seperti:

1) Mentauhidkan Allah

2) Beribadah kepada Allah

3) Bertaqwa kepada Allah

4) Berdoa khusus kepada Allah

5) Zikrulloh

6) Bertawakal, bersabar, dan bersyukur kepada Allah SWT Hasanah, 2016).

b. Akhlak terhadap sesama manusia. Akhlak terhadap sesama manusia merupakan sikap seseorang terhadap orang lain. Sikap-sikap yang harus 


\section{eL-Muhbib}

Jurnal Pemikiran dan Penelitian Pendidikan Dasar

ISSN 2614-1051 Volume 5 Nomor 2 Desember 2021

dikembangkan, antara lain; menghormati perasaan orang lain dengan bertutur kata yang baik dan tidak menyinggung, memberi salam dan menjawab salam, memenuhi janji, pandai berterima kasih, tidak mencari-cari kesalahan orang lain, dan lain sebagainya.

c. Akhlak terhadap alam. Ada kewajiban manusia untuk berakhlak kepada alam sekitarnya, ini didasarkan hal-hal sebagai berikut:

1) Bahwa manusia itu hidup dan mati di alam, yaitu bumi.

2) Bahwa alam merupakan salah satu yang di bicarakan oleh Al-Qur'an

3) Bahwa Allah memerintahkan manusia untuk menjaga pelestarian alam, agar kehidupannya menjadi makmur

4) Manusia berkewajiban mewujudkan kemakmuran di muka bumi.

\section{Akhlak Dalam Pendidikan}

Untuk membentuk kepribadian dan akhlak yang baik pada seseorang tentu saja membutuhkan latihan, bimbingan dan pengarahan dalam bentuk pendidikan, yaitu pendidikan akhlak (Rodiah, 2010). Sebagaimana telah diketahui bersama bahwa setiap manusia lahir dengan membawa fitrah, yaitu keimanan terhadap Allah dan potensi untuk menerima kebaikan. Yang hanya dengan pendidikan, potensi itu dapat dipertahankan dan di kembangkan seperti telah di sabdakan oleh Nabi SAW "Setiap anak yang dilahirkan itu dalam keadaan suci, kedua orang tuanyalah yang menjadikan Yahudi, Nasrani atau Majusi". (HR. Bukhari)

Maka jelaslah bahwa hanya dengan pendidikan potensi fitrah manusia itu dapat diarahkan untuk mengembangkan potensi-potensinya menuju akhlak yang mulia melalui metode-metode tertentu sehingga diharapkan dengan pendidikan akhlak yang mulia dan tentram dalam jiwanya suatu kesadaran untuk senantiasa mengamalkannya baik dalam hubungannya dengan Tuhan, sesamanya dan alam semesta. Pendidikan akhlak berkisar tentang persoalan kebaikan dan kesopanan, tingkah laku yang terpuji serta berbagai persoalan yang timbul dalam kehidupan sehari-hari dan bagaimana seharusnya seorang siswa bertingkah laku. Pendidikan akhlak ini sangat penting diterapkan untuk pembinaan atau pembentukkan tingkah lakunya (Rodiah, 2010).

Dalam pandangan Ibnu Sina sangat menekankan pentingnya pendidikan akhlak, semata-mata disebabkan karena akhlak sumber segala-galanya dan kehidupan bergantung pada akhlak (Futuh, 2002). Begitu pula dengan pandangan Al-Ghazali dalam Riadi (2017: 101) yang menghendaki agar pendidikan itu dilandasi dengan agama dan akhlak. Landasan berakhlak itu sendiri adalah:

a. Al-Qur'an. Akhlak Rasulullah adalah akhlak Al-Qur'an. Rasulullah juga diibaratkan Al-Qur'an yang berjalan.

b. As-Sunnah. Mengikuti sunnah berarti mengikuti cara Rasulullah bersikap, bertindak, berfikir, dan memutuskan. Seperti hadis Rasulullah yang berbunyi 


\section{eL-Muhbib}

Jurnal Pemikiran dan Penelitian Pendidikan Dasar

ISSN 2614-1051 Volume 5 Nomor 2 Desember 2021

"Sesungguhnya Aku di utus hanya untuk menyempurnakan akhlak mulia" (HR. Imam Malik). Salah satu ayat tentang pendidikan akhlak adalah Al-Qur'an surah Al-Maidah ayat 88 sebagai berikut: "Dan makanlah makanan yang halal lagi baik dari apa yang Allah telah rezekikan kepadamu, dan bertaqwalah kepada Allah yang kamu beriman kepada-Nya" (Kementrian Agama, 2010).

Dalam arti ayat diatas Allah menegaskan dan mengajarkan kepada hambanya agar memakan makanan yang halal dan baik sebagai rezeki yang diberikan Allah kepada hamba-Nya. Pendidikan akhlak yang terkandung dalam ayat ini adalah bagaimana cara seseorang untuk mendapatkan rezeki tersebut. Allah mengajarkan kepada hamba-Nya untuk mencari rezki itu dengan cara yang halal yang di ridhai Allah SWT.

\section{Bentuk Penanaman Akhlak di Sekolah}

Banyak peranan yang diperlukan dari seorang guru sebagai pendidik atau siapa saja yang menerjunkan dirinya dalam pendidikan akhlak ini. Ada beberapa peran dalam pendidikan akhlak (kepribadian) anak didik yang merupakan bagian penanaman nilai akhlakul karimah sebagai akhlak yang dianjurkan Rasulullah SAW, diantaranya sebagai berikut:

a. Keteladanan. Seorang pendidik yang baik tentunya harus memberikan teladan terhadap anak didik karena dengan beginilah usaha dalam rangka pendidikan akhlakul karimah pada siswa bisa berhasil dengan baik, hal ini bisa dikatakan sangat bergantung pada guru sebagai pendidik. Contohnya guru selalu mengerjakan amalan-amalan terpuji dengan harapan menanamkan nilai-nilai tersebut kepada siswa melalui tindakan nyata.

b. Nasehat. Pada lembaga pendidikan formal, nasehat bisa disampaikan melalui pengajaran dikelas dan melalui bimbingan khusus mengenai agama atau melalui bimbingan dan penyuluhan. Pada masa ini anak didik berada pada jiwa yang masih belum stabil, sehingga sangat diperlukan bimbingan untuk mengarah sikap dan perilaku mereka kea rah yang lebih baik.

c. Pembiasaan. Di lembaga sekolah, usaha guru meberikan pembiasaan ini sangat erat hubungannya dengan penerapan tata tertib sekolah, karena tata tertib sekolah mengatur segala tingkah laku siswa, baik dalam tata cara berpakaian, bergaul, belajar sikap terhadap teman, guru dan lingkungan disekitar mereka.

d. Pengawasan. Pengawasan menjadi suatu proses dimana pemimpin ingin mengetahui apakah hasil pelaksanaan pekerjaan yang dilakukan oleh bawahannya sesuai dengan rencana, perintah, tujuan, atau kebijakan yang ditentukan (Syarif, 2017: 23). 
eL-Muhbib

Jurnal Pemikiran dan Penelitian Pendidikan Dasar

ISSN 2614-1051 Volume 5 Nomor 2 Desember 2021

\section{METODE PENELITIAN}

Penelitian ini menggunakan jenis data kualitatif. Penelitian kualititatif mempelajari situasi nyata dengan mengadakan kontak langsung dan dekat dengan orang-orang, situasi-situasi serta fenomena-fenomena yang dipelajari, pengalaman pribadi peneliti untuk mencari penemuan-penemuan dalam konteks sosial, historis dan temporal (Margono, 2003: 36). Penelitian kualitatif menghasilkan data deskriptif berupa kata-kata tertulis atau lisan dari orang-orang dan perilaku yang dapat diamati terkait dengan strategi pembinaan akhlakul karimah melalui kegiatan ekstrakurikuler pada siswa kelas IV B MIN Tolobali Kota Bima. Adapun sumber data dalam penelitian ini ada dua yaitu sumber data primer dan sekunder. Sumber data primer antara lain Kepala Sekolah, Wakasek Kurikulum, Guru Bahasa Indonesia dan Matematika, serta siswa kelas IV B sebanyak 5 orang siswa. Sedangkan data sekunder antara lain berupa data guru dan siswa, tata letak sekolah, gambaran kegiatan ekstrakurikuler siswa, tata tertib dan aturan yang berlaku di sekolah dan manajemen sekolah MIN Tolobali Kota Bima.

Dalam hal pengumpulan data ada beberapa metode yang di gunakan yaitu; Observasi, Wawancara dan Dokumentasi. Adapun instrumen penelitian yang digunakan untuk mempermudah penelitian dalam pengumpulan data terdiri daro pedoman observasi, pedoman wawancara dan pedoman dokumentasi terkait dengan strategi pembinaan akhlakul karimah melalui kegiatan ekstrakurikuler pada siswa kelas IV B MIN Tolobali Kota Bima. Selanjutnya Kegiatan analisis data penelitian dilakukan secara interaktif dengan siklus yang berulang-ulang, dengan menggunakan Model analisisi Miles dan Huberman dalam tiga tahapan analisis mulai darai tahap Reduksi data, Penyajian data dan Penarikan kesimpulan (konklusi) penelitian yang terkait strategi pembinaan akhlakul karimah melalui kegiatan ekstrakurikuler pada siswa kelas IV B MIN Tolobali Kota Bima.

\section{HASIL DAN PEMBAHASAN}

\section{Bentuk Pembinaan Akhlakul karimah melalui Kegiatan Ekstrakurikuler pada Siswa Kelas IV B MIN Tolobali Kota Bima}

Untuk melihat pembinaan akhlakul karimah siswa melalui kegiatan ekstrakurikuler maka dapat dilihat dari kegiatan yang dikembangkan oleh sekolah seperti, kegiatan english club, arabian club, pembinaan olimpiade matematika dan sains, kegiatan pramuka, kelompok drum band, olahraga senam bersama, pembinaan tahfiz, kelompok dokter kecil, safari ramadhan dan kebiasaan sholat berjamaah yaitu sholat dhuha sebelum pelajaran dimulai dan sholat dzuhur sesudah pelajaran berlangsung serta kegiatan literasi. Bentuk pembinaan akhlak ini merupakan suatu usaha yang dilakukan dengan sadar, sungguh-sungguh, tererncana dan konsisten terhadap perubahan perilaku, watak, tabi'at maupun 


\section{eL-Muhbib}

Jurnal Pemikiran dan Penelitian Pendidikan Dasar

ISSN 2614-1051 Volume 5 Nomor 2 Desember 2021

perangai seseorang dengan cara membimbing, mengarahkan, dan mengembangkan pengetahuan, sikap, maupun keterampilannya.

Pembinaan akhlakul karimah merupakan kegiatan yang dilaksanakan di dalam/luar lingkungan sekolah sebagai usaha membentuk anak dengan menggunakan sarana pendidikan dan pembinaan yang terprogram (Hartati, 2020). Pembinaan akhlakul karimah melalui kegiatan ekstrakurikuler dapat dilakukan dengan banyak kegiatan, diantaranya seperti kegiatan English club, Arabian club, pembinaan olimpiade matematika dan Sains, kegiatan pramuka, kelompok drum band, olahraga senam bersama, pembinaan tahfiz, kelompok dokter kecil, safari ramadhan dan kebiasaan sholat berjamaah yaitu sholat dhuha sebelum pelajaran dimulai dan sholat dzuhur sesudah pelajaran berlangsung serta kegiatan literasi. Untuk saat ini beberapa kegiatan itu diberhentikan kegiatannya secara tatap muka dan dilakukan secara online karena suasana pandemi.

a. English club

English Club MIN Tolobali Kota Bima dikomandai oleh 2 orang pembina muda yaitu Syafruddin, S.S, dan Agustina, S.Pd. Bentuk kegiatan adalah Pembinaan kemampuan berpidato (speech), kemampuan bericara dan bercerita dengan bahasa inggris, kemampuan percakapan (cenversation) secara baik dan benar. Dengan volume kegiatan sebanyak 2 kali dalam seminggu diharapkan dapat mencetak kemampuan berbahasa Inggris yang mumpuni.

b. Arabian Club

Kelompok Ta'lim Bahasa Arab dengan jumlah keanggotaan sebanyak 50 orang siswa, setiap tahun Pembina mengadakan pemilihan terhadap pengurus organisasinya sebagai penanggung jawab kegiatannya. Dibawa binaan langsung oleh ibu Rahmawati, S.Ag dengan intensitas kegiatan 1 kali seminggu dengan materi Khithabah (Pidato), materi Muhadatsah (Percakapan) dan Kitabah (Menulis).

c. Pembinaan Olimpiade Matematika dan Sains

Salah satu kegiatan Unggulan di MIN Tolobali Kota Bima saat ini adalah pembinaan Olimpiade Matematika dan Sains. Kegiatan ini dibina langsung oleh Guru Matematika yaitu Jumrah, S.Pd. sedangkan untuk Bidang Sains dibina oleh Kamarunnisa, S.Pd dan Sri Haerunisa, S.Si. Pembinaan yang dilakukan tidak hanya dilakukan di sekolah, namun juga di luar sekolah. Hal ini dilakukan untuk menciptakan suasana pembinaan yang menyenangkan.

d. Pramuka

Secara harafiah pramuka dapat diartikan "paling depan". Kata pramuka merupakan rangkaian kata "Pra, Mu, Karana". Pra yang merupakan singkatan dari kata "praja" yang berarti rakyat atau warga. Mu singkatan dari kata "Muda" yang berarti belum dewasa. Ka singkatan dari "karana" yang berarti perbuatan, 


\section{eL-Muhbib}

Jurnal Pemikiran dan Penelitian Pendidikan Dasar

ISSN 2614-1051 Volume 5 Nomor 2 Desember 2021

penghasilan (Mukhlis, 2016: 38). Pramuka dibina langsung oleh St. Kalisom, S.Pd.I dengan jumlah anggota 80 orang. Di samping itu mereka juga mengadakan kemah bakti untuk GUDEP MIN Tolobali Kota Bima di sekolah atau kegiatan Hecking di luar sebanyak 2 kali satu semester. Di Bumi Perkemahan Lampe Kota Bima mereka juga partisipasi dalam kegiatan Kemah Bakti bersama seluruh anggota Pramuka se-Kota Bima.

e. Pembinaan Drumband

Drumband adalah sekelompok barisan orang yang memainkan satu atau beberapa lagu dengan menggunakan sejumlah kombinasi alat musik (tiup, perkusi dan sejumlah instrument pit) secara bersama-sama. Biasanya diiringi dengan aksi tarian yang dilakukan oleh sejumlah pemain bendera (Mauliddiyah, 2018). Pembinaan drumband langsung ditangani oleh Dopu Teibang, S.Pd.I., yang dilaksanakan 3 (tiga) kali dalam seminggu. Pola pembinaan yang dilaksanakan selama ini sangat efektif. Hal ini terlihat dari jumlah siswa yang mengikuti pembinaan yang semakin meningkat. Salah satu model pembinaannya adalah berjenjang sesuai dengan kelas siswa yang mengikuti. Setelah menguasai penggunaan drum band, siswa diharuskan melakukan eksebisi di setiap kegiatan sosial, seperti Pawai Pembukaan MTQ, Pawai Hari Besar Keagamaan, Hari Ulang Tahun Kota Bima dan Hari Amal Bhakti Kementerian Agama Kota Bima.

f. Olahraga

Pembinaan yang fokusnya dalam bidang olahraga adalah Atletik, Sepak Bola, Tenis Meja. Pembina akan memilih siswa yang berbakat dalam cabang olahraga tersebut dan selanjutnya akan dibina secara berkala untuk mengasah kemahiran mereka. Berkat pembinaan cabang olahraga itu maka terbentuklah timtim yang diprioritaskan untuk dibawah ke dalam kompetisi dan turnamen. Dalam perjalanan pembinaan ini yang terpenting adalah berjalan terus dan tetap termotivasi bukan hanya sekedar sewaktu ada persiapan untuk event-event tertentu saja. Dengan kemauan keras dari siswa dan pembina maka al-hamdulillah sudah banyak menghasilkan prestasi olahraga dalam berbagai kompetisi yang diikutinya.

g. Pembinaan Tahfiz

Program unggulan untuk mencetak generasi Hafiz adalah melalui pembinaan Tahfiz yang langsung dibina oleh Nurhayati, S.Pd.I. dalam setiap pembinaan, siswa diminta untuk menyetor hafalan kepada Pembina, yang dilaksanakan setiap 1 kali se-minggu. Program ini menjadi program favorit yang diikuti oleh siswa MIN. Hal ini terlihat dari semakin meningkatnya jumlah penghafal zuz ammah. Untuk menilai keberhasilan program ini, sekolah telah mengadakan kegiatan disetiap hari selasa, rabu dan kamis bahwa sebelum dan sesudah kegiatan belajar mengajar berlangsung itu siswa dibiasakan membaca 


\section{eL-Muhbib}

Jurnal Pemikiran dan Penelitian Pendidikan Dasar

ISSN 2614-1051 Volume 5 Nomor 2 Desember 2021

ayat-ayat pendek dan setiap akhir tahun pelajaran, akan diadakan lomba sekaligus khataman massal. Diharapkan, melalui program ini siswa mampu menjadi pilar tahfiz Al-Qur'an.

h. Safari Ramadhan

Safari Ramadhan merupakan kegiatan rutin yang diselenggarakan guru dan Siswa MIN Tolobali Kota Bima di seluruh Masjid di Kota Bima selama bulan Ramadhan lima tahun terakhir. Safari ini dihajatkan sebagai kelanjutan dari kegiatan pembinaan IMTAQ, untuk mengukur sejauh mana keberhasilan pembinaan siswa dan siswa mampu menampilkan diri sebagai muballig untuk masyarakat yang ada di Kota Bima. Di era milenial ini, pengembangan aspek spiritual anak menjadi aspek terpenting dan menjadi PR tersendiri bagi guru sebagai pendidik. Karena waktu yang terfokuskan dalam kegiatan pembelajaran. Dilihat dari hasil penelitian di atas maka peneliti dapat menyimpulkan bahwa beberapa kegiatan ekstrakurikuler di atas telah menjadi pondasi yang cukup kuat bagi MIN Tolobali Kota Bima dalam mengepangkan sayap go internasional. Prestasi-prestasi tersebut telah menjadi acuan dasar siswa dalam mengembangkan kemampuan mereka. Sehingga siswa yang tergabung dalam kegiatan dapat di bina sekaligus membentuk pribadi-pribadi yang berakhlakul karimah.

\section{Faktor Penghambat Pembinaan Akhlakul Karimah melalui Kegiatan Ekstrakurikuler pada Siswa Kelas IV B MIN Tolobali Kota Bima.}

Terlepas dari keberhasilan suatu usaha yang dikembangkan, pasti tidak luput dari hambatan-hambatan yang pernah dilalui. Menuai banyak prestasi bukan berarti melewati jalan lurus tampa hentakan-hentakan yang terjal. Berikut uraian dari hambatan yang pernah dialami guru maupun siswa sendiri dalam pembinaan akhlakul karimah:

a. Jarak

Jarak adalah suatu pengukuran nomerik yang menunjukkan seberapa jauh suatu benda berubah posisi melalui suatu lintasan tertentu (Wikipedia, 2020). Jarak menjadi kendala utama di karenakan adanya larangan pemerintah atas masalah pandemi yang melanda. Keberadaan siswa yang lebih banyak di rumah mengharuskan pihak guru atau wali kelas bekerja sama dengan para orang tua siswa dalam mengetahui apa saja yang dilakukan oleh siswa saat berada di rumah masing-masing.

b. Pembullyan

Penindasan, perundungan, perisakan, atau pengintimidasian (dalam bahasa inggris: bullying) adalah penggunaan kekerasan, ancaman, atau paksaan untuk menyalahgunakan atau mengintimidasi seseorang. Perilaku ini dapat menjadi suatu kebiasaan dan melibatkan ketidakseimbangan kekuasaan sosial atau fisik. 


\section{eL-Muhbib}

Jurnal Pemikiran dan Penelitian Pendidikan Dasar

ISSN 2614-1051 Volume 5 Nomor 2 Desember 2021

Adanya sikap bullying ini menjadi kendala sekaligus masalah dasar dalam pembentukan akhlakul karimah siswa. Hal inilah yang memicu lahirnya pembinaan akhlakul karimah melalui kegiatan ektrakurikuler dengan berbagai bentuk kegiatan binaan.

c. Kondisi lingkungan keluarga

Lingkungan keluarga sebagai Madrasah pertama bagi seorang anak, menjadi penentu akhlaknya di masa mendatang. Keberhasilan suatu proses pendidikan dalam membentuk akhlak yang baik bagi siswa juga didasari dari hasil pendidikan yang ia miliki dalam lingkungan keluarga. Transformasi nilai-nilai yang pernah ia pelajari dalam lingkungan keluarga dengan hal baru yang ia ketahui di sekolah akan menjadi pondasi dalam membenahi dirinya di masa depan. Keadaan orang tua yang mementingkan urusan pekerjaan terkadang berdampak pada proses pertumbuhan perilaku siswa. Akibat kurangnya perhatian dan bimbingan dari orang tuanya, siswa-siswa seperti ini akan mendatangkan masalah di sekolah untuk menarik perhatian orang tuanya seperti tindakan bolos di jam pelajaran berlangsung, tidak mengerjakan PR, mengganggu temantemannya, atau tindakan-tindakan yang berbau negatif.

\section{d. Kecenderungan bermain game}

Game dalam bahasa inggris berarti permainan. Permainan biasa dimainkan dengan aturan tertentu sehingga ada kalah dan ada yang menang. Bermain game menjadi kebiasaan yang tidak bisa dipisahkan dari dalam diri siswa. Game dengan banyak jenis yang bisa dimainkan menjadi pemicu siswa sehingga kecenderungan dan melalaikan kewajibannya seperti tidak mengerjakan tugas, tidak teratur dalam beribadah, melalaikan diri dalam permainan, dan masih banyak lagi dampak lain. Berdasarkan persoalan-persoalan yang timbul inilah guru dituntut untuk kreatif dalam mengembangkan desain kegiatan belajar mengajar meski dalam kondisi tidak saling berhadap-hadapan (luring). Kegiatan belajar mengajar secara daring tidak membuat guru menyerah akan pembinaan akhlakul karimah siswa. Melalui komunikasi dan kerja sama guru dengan kepala sekolah, kerja sama guru dengan guru lain maupun kerja sama guru dengan para orang tua siswa.

Berikut beberapa solusi yang telah dilakukan oleh pihak guru dan sekolah dalam menangani hambatan-hambatan di atas:

a. Berdiskusi dengan kepala sekolah. Sebagai sosok panutan paling berpengaruh, kepala sekolah selalu menjadi teman curhat dan musyawarah para guru yang mengalami masalah dalam kelas. Hal ini bertujuan untuk mencari solusi secara bersama-sama bagaimana menangani hal yang terjadi sebagai tombak keberhasilan di masa mendatang.

b. Kerja sama para guru. Sebagai pengajar dan pentransfer ilmu pengetahuan, guru menjadi penanggung jawab utama dalam mendidik maupun membina 


\section{eL-Muhbib}

Jurnal Pemikiran dan Penelitian Pendidikan Dasar

ISSN 2614-1051 Volume 5 Nomor 2 Desember 2021

siswanya. Kerja sama yang dilakukan oleh para guru di MIN Tolobali Kota Bima sendiri biasanya, berkaitan dengan persoalan siswa yang menjadi tanggung jawabnya, berkaitan dengan metode, strategi, kondisi seperti apa yang akan digunakan dalam kegitan belajar mengajar berlangsung, maupun mencocokkan soal-soal yang akan dijadikan penilaian, baik dalam penilaian harian maupun penilaian-penilaian dalam ujian tengah semester, dan ujian semester.

c. Kerja sama guru dengan orang tua siswa. Kerja sama yang dikembangkan oleh para guru di MIN Tolobali Kota Bima biasanya melalui sistem whatsapp grup. Melalui sistem itulah guru dapat terus memantau kegiatan siswa melalui cerita dari orang tuanya. Apabila terdapat kendala, maka dapat di diskusikan secara langsung oleh guru dengan orang tua siswa untuk memecahkan masalah tersebut. Terkadang juga guru menggunakan kedua cara di poin a dan $\mathrm{b}$ di atas, kemudian menyampaikan kepada orang tua siswa apabila dalam perealisasiannya itu membutuhkan kerjasama dengan orang tua siswa.

\section{SIMPULAN}

Bentuk pembinaan akhlakul karimah di MIN Tolobali Kota Bima melalui kegiatan ekstrakurikuler terbukti sangat berpengaruh pada perubahan akhlak siswa. Hal ini terbukti dari sikap siswa yang sudah jarang terlihat seperti bullying, selalu mematuhi tata tertib dan arahan dari guru. Kegiatan ektrakurikuler tersebut mencakup kegiatan sebagai berikut: a) kegiatan english club, b) kegiatan arabian club, c) kegiatan pembinaan olimpiade matematika dan sains, d) kegiatan pramuka, e) kegiatan pembinaan drumband, f) kegiatan pembinaan tahfiz, dan g) kegiatan olahraga. Hal ini dapat diukur dari tingkat keberhasilan siswa dalam menuai prestasi dalam bidang-bidang yang mereka geluti. Semangat siswa dalam mengembangkan potensi yang di miliki dengan bergabung dalam kegiatan ekstrakurikuler yang mereka minati. Perubahan perilaku siswa yang pada dasarnya suka membully menjadi rutinitas kerjasama baik dalam mengerjakan tugas kelompok maupun dalam melakukan kegiatan yang bernuansa positif seperti dalam kegiatan ekstrakurikuler. Adapun faktor penghambat dalam pembinaan akhlakul karimah melalui kegiatan ekstrakurikuler pada siswa kelas IV B MIN Tolobali Kota Bima ini ada beberapa khususnya setelah pandemi dapat diuraikan sebagagai berikut: a) jarak atau kegiatan belajar mengajar yang dilakukan secara daring, b) bullying, karena menghambat proses pembinaan akhlakul karimah siswa, c) kondisi lingkungan keluarga, dan d) kecenderungan siswa dalam bermain game. 
eL-Muhbib

Jurnal Pemikiran dan Penelitian Pendidikan Dasar

ISSN 2614-1051 Volume 5 Nomor 2 Desember 2021

\section{DAFTAR PUSTAKA}

Futuh, Abdul. 2002. Ali Al-jumbulati. Jakarta: Rineka Cipta.

Hartati, Lisa. 2020. "Pembinaan Akhlakul Karimah Siswa Madrasah Aliyah Darul Hikmah Pekanbaru", http://repository.uinsuska.ac.id/13114/7/7.\%20bab\%20ii_2018577pai.pdf di akses pada Jum'at 13 November.

Hasanah, Zulfa Binta. 2016. "Penanaman Nilai-Nilai Akhlakul Karimah di Madrasah Ibtidaiyah Negeri Purwokerto". Skripsi”, Purwokerto, 2016.

Hasil observasi pada hari selasa, 25 Oktober 2020, pukul 07.00 - 09.15.

Manan, Syaepul. 2020. "Pembinaan Akhlak Mulia Melalui Kebiasaan dan Keteladanan", http://jurnal.upi.edu/file/05_pembinaan_akhlak_mulia__manan2.pdf diambil tanggal 15 Oktober.

Margono. 2003. Metodologi Penelitian. Jakarta: Rineka Cipta.

Mukhlis. Moh. Imam. 2016. Implementasi Kegiatan Pramuka Dalam Membentuk Karakter Disiplin Anggota Gerakan Pramuka Di Sekolah Dasar Negeri Sukun 3 Malang". "Sktipsi”, UIN Maulana Malik Ibrahim Malang.

Riadi, Dayun, dkk. 2017 Ilmu Pendidikan Islam. Yogyakarta: Pustaka Pelajar.

Rodiah, dkk. 2020. Studi Al-Qur'an Metode Dan Konsep. Yogyakarta: Elsaq Press.

Syarif, Jamal. 2016 Penanaman Akhlakul Karimah Oleh Guru Kepada Siswa Sekolah Dasar Negeri Murung Raya 1 Banjarmasin.

Syukurman. 2016. Sosiologi Pendidikan: Memahami Pendidikan dari Aspek Multicultural.Yogyakarta: Elmatera Publishing.

Wahab, Rohmalina. 2016. Psikologi Belajar. Jakarta: PT Raja Grafindo Persada.

Wikipedia. 2020. "jarak", dalam https://id.wikipedia.org/wiki/jarak diambil pada tanggal 12 November. 